\section{The Influence of Porosity on the Elasticity and Strength of Alumina Ceramics}

\author{
Nikolai L. Savchenko = Institute of Strength Physics and Materials Science SB RAS, Tomsk (Russia) \\ Irina N. Sevostyanova - Institute of Strength Physics and Materials Science SB RAS, Tomsk (Russia) \\ Tatiana Yu. Sablina - Institute of Strength Physics and Materials Science SB RAS, Tomsk (Russia) \\ LUCIA MoLnÁR - University of Miskolc, Egyetemváros, Miskolc (Hungary) \\ RóBERT GÉBER - University of Miskolc, Egyetemváros, Miskolc (Hungary)
}

LÁszLó A. GömZE - University of Miskolc, Egyetemváros, Miskolc (Hungary) - femgomze@uni-miskolc.hu SERGEY N. KuLKov - Institute of Strength Physics and Materials Science SB RAS, Tomsk (Russia) Tomsk State University (TSU), Tomsk (Russia) • kulkov@ms.tsc.ru

LudMILA N. GöMZE • IGREX Engineering Service Ltd, Igrici (Hungary) • igrex2009@yandex.ru Received: 28. 06. 2014. " Érkezett: 2014. 06. 28. " http://dx.doi.org/10.14382/epitoanyag-jsbcm.2014.9

\section{Abstract}

This work investigates the behavior of porous alumina ceramics (within the porosity range of $18 \%$ to $70 \%$ ) when subjected to deformation by compression and shear. The analysis of straindeformation curves showed that there was a transition from a typically brittle state for relatively dense ceramics ( $\leq 20 \%$ porosity), to a pseudo-plastic one with a high rate of porosity (above $50 \%$ ). The values of the modulus of elasticity, shear modulus and Poisson's ratio decrease with an increase in volume in the pore space of $\mathrm{Al}_{2} \mathrm{O}_{3}$ ceramics, which correlates with the appearance of multiple cracking during the deformation of ceramics with a high level of porosity.

Keywords: Alumina, deformation, modulus of elasticity, plasticity, porosity, shearing, strain, strength, stress.

\section{Introduction}

It is known that the porosity of brittle materials can have significant influence on their physical (mechanical, thermal, electrical) properties. Young's modulus, shear modulus and Poisson's ratio are essential parameters in the studies of advanced material mechanics [1-3]. In addition, the macroscopic behavior of ceramics can vary from brittle to quasi-plastic depending on the pore space volume [3]. That is why the investigation of the evolution of deterioration in a brittle porous material at different levels of scale and the subsequent damage depending on the deformation rate, constraint, etc. is of considerable interest [4-9] in terms of the emergence of a structural hierarchy of deformation and failure in similar brittle materials (ceramics, stones).

The objective of the work is to study the relations between parameters such as porosity, compressive strength, Young's modulus, shear modulus, measured in the process of mechanical loading under compression and shear, as well as structures of damage and deformation in alumina ceramics.

\section{Experimental materials and methods}

$\mathrm{Al}_{2} \mathrm{O}_{3}$ ceramics with different porosity values (18\%-70\%) were made of powders obtained via thermal decomposition of aqueous nitric-acid metallic salt solutions in high-frequency discharge plasma [10]. The initial powders and a 3\% polyvinyl alcohol solution were pressed by a hydraulic press under $10 \mathrm{kN} / \mathrm{cm}^{2}$ pressure in steel die molds in order to obtain cylindrical $(10 \mathrm{~mm}$ in diameter, $15 \mathrm{~mm}$ in height) and cubic (10 mm each side) shapes.
Nikolai L. Savchenko, PhD

Education: 1987: Tomsk Polytechnic Universityengineer.1991-1994: Institute of Strength Physics and Materials Science of the Russian Academy of Sciences in Tomsk - PhD student. 1995: PhD.degree from the Institute of Strength Physics and Materials Science of the Russian Academy of Sciences in Tomsk. Field of research: Structure and mechanical property of porous ceramics based zirconia and alumina.

Tatiana Yu. Sablina, PhD Education: 1989: Tomsk Polytechnic Universityengineer.1991-1994: Institute of Strength Physics and Materials Science of the Russian Academy of Sciences in Tomsk - PhD student. 1995: PhD.degree from the Institute of Strength Physics and Materials Science of the Russian Academy of Sciences in Tomsk. Field of research: Structure and mechanical property of porous ceramics based zirconia and alumina.

Irina N. Sevostyanova, PhD Education: 1987: Tomsk Polytechnic Universityengineer.1993-1996: Institute of Strength Physics and Materials Science of the Russian Academy of Sciences in Tomsk - PhD student. 2001: PhD.degree from the Institute of Strength Physics and Materials Science of the Russian Academy of Sciences in Tomsk. Field of research: Structure and mechanical property of porous ceramics based zirconia and alumina.

Róbert Géber, PhD has finished his MSc at the Materials Science and Engineering Faculty in University of Miskolc (Hungary) in 2007. Under guidance Prof. Gömze he prepared and successfully completed his PhD thesis in 2013. At the present time he is assistant professor in the Inst. Dep. of Ceramics and Silicate Engineering and author or co-author more than 20 articles

Lucia Molnár

is a BSc student at the Materials Science and Engineering Faculty in University of Miskolc (Hungary) and under guidance Prof. Gömze she is participating in the research works which are made under collaboration agreement between Tomsk State University (Russia) and University of Miskolc (Hungary).

Prof. Sergey N. Kulkov

Prof. Kulkov is head of Department of Ceramics in the Institute of Strength Physics and Materials Science of the Russian Academy of Science since 1989. He has got scientific degrees "Doctor of Physics and Mathematical Sciences" in 1990. Since 1992 he's working as professor both in Tomsk State University and in Tomsk Polytechnic University. In 1997 he had a Soros Professor grant. His research works are represented in 5 books, more than 150 articles, 18 patents and many International Symposiums and Conferences. At present he is head of department "Theory of Strength and Mechanic of Solids", member of "The American Ceramic Society” of „The APML International" and the DYM AT Society (France).

Prof. László A. Gömze Establisher (in July 1st, 1999) and head of Department of Ceramics and Silicate Engineering in the University of Miskolc, Hungary. Since then 7 students from the department have successfully completed their PhD theses and 4 of them were managed by Prof. Gömze. He is author or coauthor of 2 patents, 5 books and more than 250 scientific papers. Recently, he is the chair of the International Organization Board of ic-cmtp ${ }^{3}$ the $3^{\text {rd }}$ International Conference on Competitive Materials and Technological Processes (2014) and ic-rmm ${ }^{2}$ the $2^{\text {nd }}$ International Conference on Rheology and Modeling of Materials (2015).

Dr. Ludmila N. Gömze has finished her MSc as civil engineer in the Moscow State Construction-Engineering University (Russia) in 1974. Since that time she lives in Hungary and has a wide range working experiments as engineer. At present time she is the managing director of the IGREX Engineering Service Ltd and is author or co-author more than 30 scientific articles. 


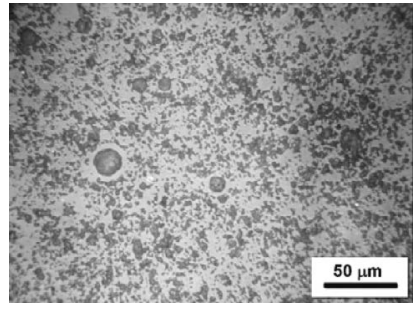

(a)

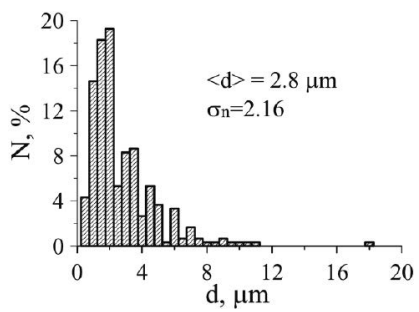

(c)

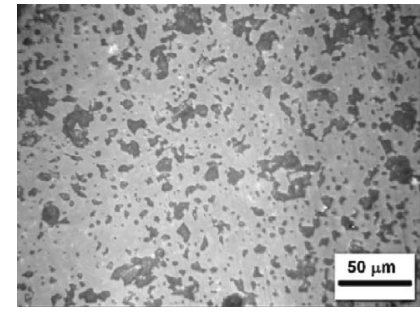

(b)

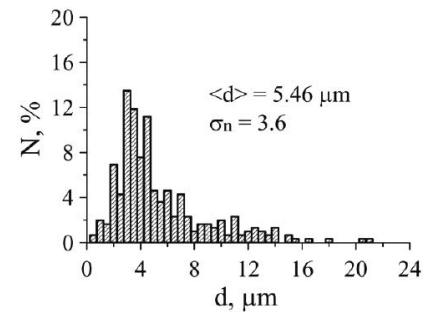

(d)
Fig. 1. Pore structure $(a, b)$ and pore size distribution (c, d) of $\mathrm{Al}_{2} \mathrm{O}_{3}$ ceramics after sintering at a temperature of: $1400^{\circ} \mathrm{C}-(a, c), 1600^{\circ} \mathrm{C}-(b, d)$.

1. ábra $\mathrm{Az} 1400^{\circ} \mathrm{C}-(a, c)$ és $1600^{\circ} \mathrm{C}-(b, d)$ hömérsékleten szinterelt $\mathrm{Al}_{2} \mathrm{O}_{3}$ kerámiák anyagszerkezete a pórusokkal $(a, c)$ és pórusméret eloszlása $(b, d)$

Sintering was performed in air at temperatures ranging from 1000 to $1650^{\circ} \mathrm{C}$ with an isothermal exposure time of one hour. The density of the sintered specimen was measured using the geometrical method. Residual porosity was calculated from the ratio of theoretical density to measured density, considering the phase composition of the obtained materials. The material structure after sintering was studied by optical metallography.

The specimens were exposed to mechanical tests in compression and shear by an universal testing machine Instron 1185 , with simultaneous recording of the loading diagram. The traversal (loading) rate was $0.2 \mathrm{~mm} / \mathrm{min}$. On the $\sigma-\varepsilon$ curves, a straight-line segment was outlined which corresponded with elastic deformation. Effective modulus of elasticity (E) and shear modulus $(G)$ were defined as the angle of a tangent line slope to a straight-line segment of the $\sigma-\varepsilon$ function curve.

\section{Results and discussion}

Investigations of ceramics structure after sintering showed that in specimens sintered at low temperatures, high porosity was observed and these pores were advantageously interpenetrating. The pore structure of $\mathrm{Al}_{2} \mathrm{O}_{3}$ ceramics sintered at $1400^{\circ} \mathrm{C}$ and $1600^{\circ} \mathrm{C}$ is shown in Fig. 1.a,b. With an increase in sintering temperature, along with decrease in pore space volume, an increase in the average pore size was observed (Fig. 1.c,d) due to the consolidation of fine pores into larger ones. According to X-ray structure analysis data, at all sintering temperatures $\mathrm{Al}_{2} \mathrm{O}_{3}$ is in a stable $\alpha$-phase.

The comparison of $\sigma-\varepsilon$ diagrams, obtained after testing ceramics with different porosity levels in compression, showed that their behavior depends on the pore space volume. The $\sigma-\varepsilon$ curve analysis of $20 \%$ porous ceramics proved that they are linear functions until material destruction, (Fig. 2.a) while deviations from the linearity (Fig. 2.b) are observed in ceramics with a higher porosity of $20 \%$ to $50 \%$ in the area of high stresses.

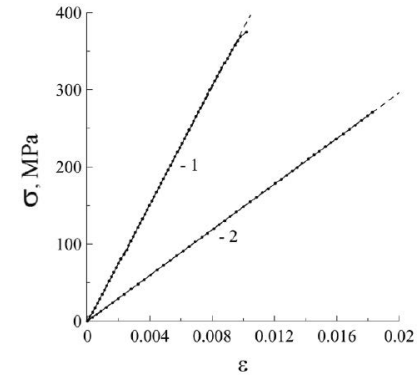

(a)

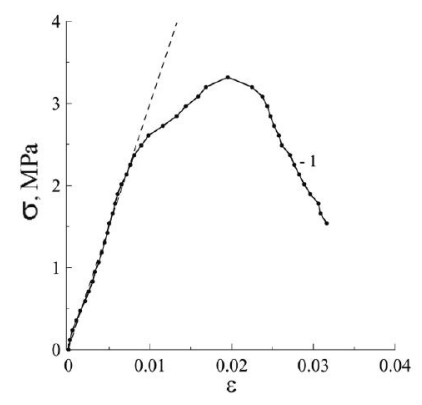

(c)

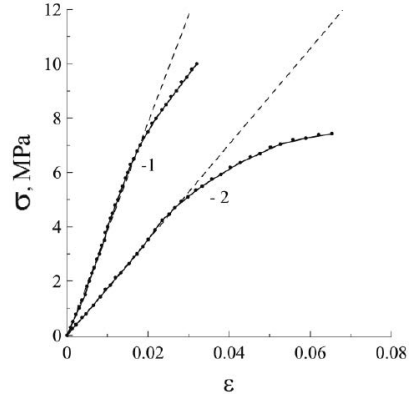

(b)

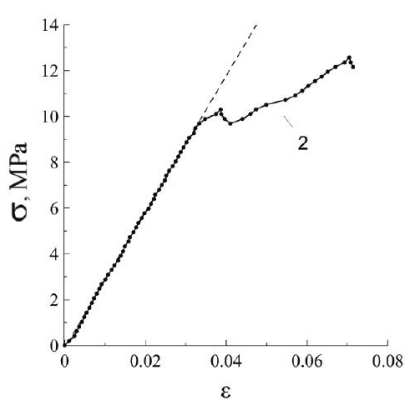

(d)
Fig. 2. Stress-strain diagrams obtained by tests in compression (curve 1) and shear (curve 2) for $\mathrm{Al}_{2} \mathrm{O}_{3}$ with porosity of: (a) - 20\% (b) - 50\%. (c) Stress-strain diagram obtained by tests in compression for alumina ceramics with a pore space volume over $60 \%$. (d) Stress-strain diagram obtained by tests in shear for alumina ceramics with a pore space volume over $60 \%$.

2. ábra A $20 \%$ (a) és $50 \%$ (b) porozitású $\mathrm{Al}_{2} \mathrm{O}_{3}$ kerámiák mért feszültség-deformáció diagramja nyomás (1 görbe) és nyírás (2 görbe) esetén; valamint a $60 \%$ porozitású kerámia feszültség-deformáció diagramja nyomás (c) és nyírás (d) esetén

Deformation diagrams of ceramics with porosity over $50 \%$ had a more complex behavior. The compression test curves mostly had a gradually descending stress arm (Fig. 2.c) which appear due to microdamages accumulated in the samples whereas the shear test curves had a slightly ascending arm after the stress fall curve portion which resulted from the stress growth (Fig. 2.d).

Observations of specimen structure after compression tests identified some differences in the nature of damage of ceramics with different porosities. In specimens with 18\%-20\% porosity, brittle fracturing of elastic specimens occurs after elastic energy accumulation. Due to elastic energy release, the specimen fully breaks down after reaching the compression strength limit. With a growth in pore space volume, damage of more localized nature is seen in ceramics and specimens do not fully break down after reaching the compression strength limit and, in general, do not lose the ability for future deformation. Specimens with a porosity near $40 \%$ after compression tests are shown in Fig. 3.a,b. It is visible that on the lateral surface of cylindrical specimens, cracks formed at a $45^{\circ}$ angle to the applied load axis (Fig. 3.a). In such ceramics, a damage zone in the form of a truncated cone with a cone angle of about $45^{\circ}$ forms after compression, while the cone basis lies almost in a static capture plane (Fig. 3.b). The deformation process of $50 \%-70 \%$ porous ceramics is accompanied with the appearance of multiple cracks directed primarily parallel to the loading axis (Fig. 3.c) on the lateral surface of the cylindrical specimen. In addition, the base 
diameter of the cone forming in the deteriorating specimen was relatively smaller in size compared to denser ceramics (Fig. 3.b), while the cone's taper angle was approximately $45^{\circ}$ (Fig. 3.d).

In the course of shear tests, specimens with $\leq 40 \%$ porosity demonstrated the emergence of a main crack which was angled $45^{\circ}$ towards the applied load (Fig. 3.e). The main crack appeared at the deformation stage right after the elastic part on the straindeformation curve. In specimens with porosity over $40 \%$, the deformation process was accompanied with the emergence of many fine cracks in different directions without the explicit main crack until the stage of complete destruction (Fig. 3.f). Fig. 3.b shows that on the edges of the specimen there are areas of material separated by developing cracks from the ceramic base, in which deformation from compression occurs.

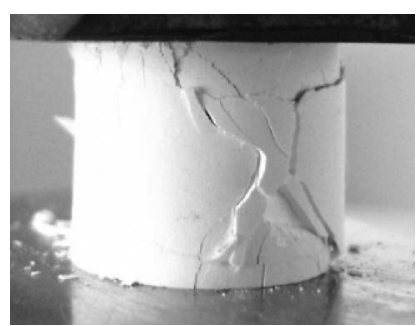

(a)

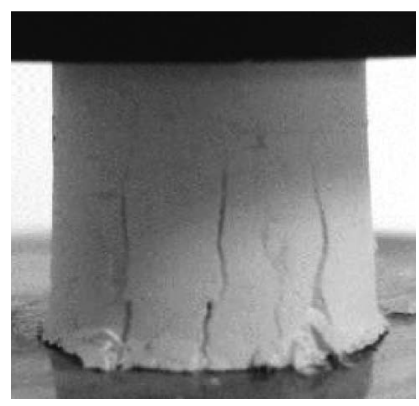

(c)

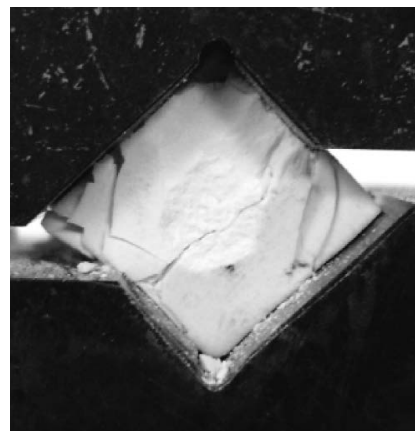

(e)

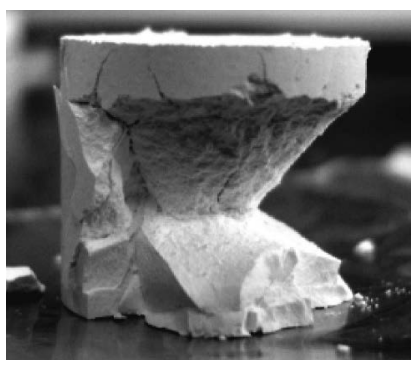

(b)

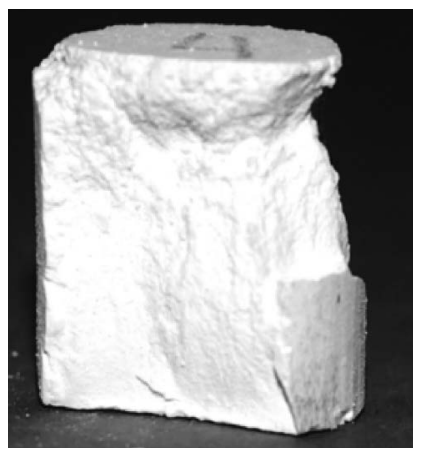

(d)

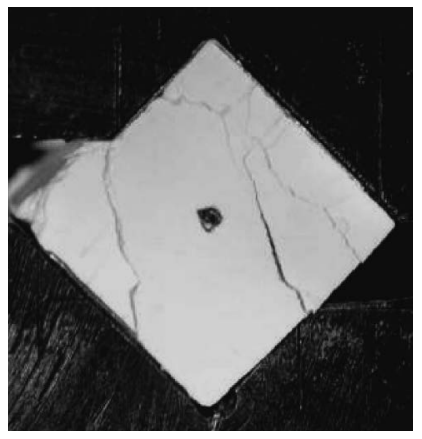

(f)
Fig. 3. The failure shape of $\mathrm{Al}_{2} \mathrm{O}_{3}$ specimens with porosities of: $(a, b) 40 \%,(c, d)$ $55 \%$ after a test in compression. The failure shape of $\mathrm{Al}_{2} \mathrm{O}_{3}$ specimens with porosities of: (e) $40 \%$; $(f) 69 \%$ after a test in shear.

3. ábra $A 40 \%(a, b), a z 55 \%(c, d)$ porozitású $\mathrm{Al}_{2} \mathrm{O}_{3}$ próbatestek állapota nyomószilárdság vizsgálat után; illetve a $40 \%(e)$ és $69 \%(f)$ porozitású $\mathrm{Al}_{2} \mathrm{O}_{3}$ próbatestek a nyírószilárdság vizsgálat után

It is known that cracks appear at the location of deformation, in the most damaged areas of the material [11]. In the case when stress is formed by an incline towards the compression of the damaged area, tension related to the presence of friction between the grip (plate) of the testing machine and adjacent ends of the sample plays a significant role in the failure [12]. Accordingly, the formation of cones inside of the collapsed samples (Fig. 3.c,d) due to the presence of friction forces and the destruction of ceramics under compression is controlled by shear stresses.

It is also known that the orientation of cracks depends on the accumulated strain limit value, or dilatancy (micro-crack saturation and their openings) [11]. As each pore is a potential source of microcracking in a porous material, and with the increase in the number of pores in a specimen, the number of such sources naturally grows, then the observable distinctions in the direction and behavior of crack spread in different porosity level ceramics (Fig. 3) are apparently the result of differing levels and natures of accumulated deformation in the form of microcracks that appear after compression and shear.

Studies of the mechanical and elastic properties of ceramics showed that within the studied intervals of pore space volume (from 0.18 to 0.72 ), the strength limit in compression and shearing, as well as the modulus of elasticity and shear modulus decrease with an increase in porosity (Fig. 4). In addition, the dependency of changes in strength properties on porosity is well-described by the law, and is near exponential.

As it is seen in Fig. 4.c, the absolute values of the modulus of elasticity and shear modulus grow closer with an increase in porosity, which shows a decrease in Poisson's ratio. It should be noted that in our case there is only a decrease in Poisson's ratio values. Determining the absolute values of Poisson's ratio in the process of mechanical testing was complicated, as experimental error constituted a value of \pm 0.3 . An identification of Poisson's ratio by measuring the rate of longitudinal and latitudinal sound waves [13] in the ceramics performed with the use of an ultrasound flaw detector showed that values for Poisson's constant decreased from 0.21 to 0.15 with a growth in pore space volume of $20 \%$ to $40 \%$.

The fact that Poisson's ratio decreases with an increase of pore space volume was previously noted in several publications [1, $13]$. In $[13,14]$ it was shown that for porous isotropic bodies, the values of Poisson's ratio depend on the pore space volume, pore geometry and Poisson's ratio values for a pore-free material state $\left(\mu_{0}\right)$. For materials with $\mu_{0}>0.2$ (including alumina ceramics), it is theoretically predicted and experimentally proven that there is a decrease in the values of Poisson's ratio with an increase in pore space volume for ceramics with different pore geometry $[13,14]$.

The decrease of values for Poisson's ratio with an increase in pore space volume can be explained by nonlinear elasticity, which similar porous ceramics display under mechanical loading $[15,16]$. Furthermore, local deformations due to relative movements and deformations of its structural components play an essential role in the deformation of objects with a similar complicated internal structure, noticeably changing the elastic properties of metals [1].

\section{Conclusions}

The analysis of stress-strain curves of porous alumina ceramics (within the porosity range of $18 \%$ to $70 \%$ ) showed 


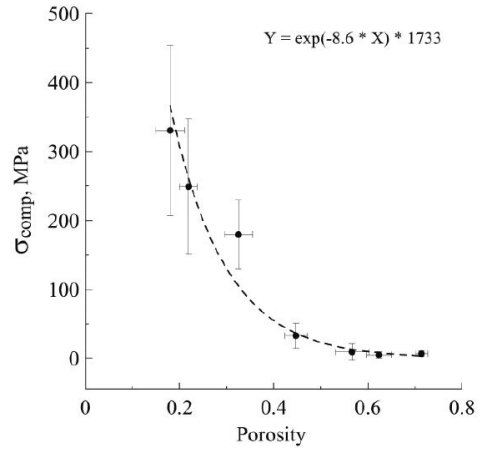

(a)

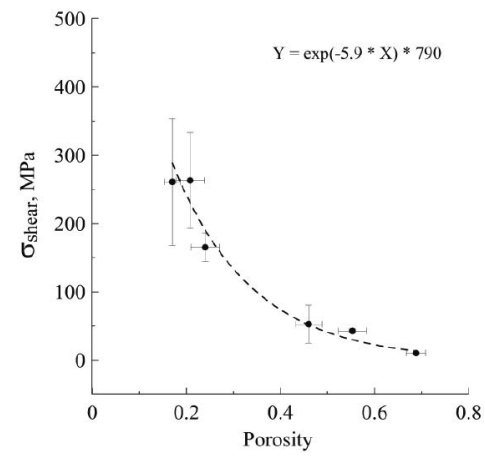

(b)

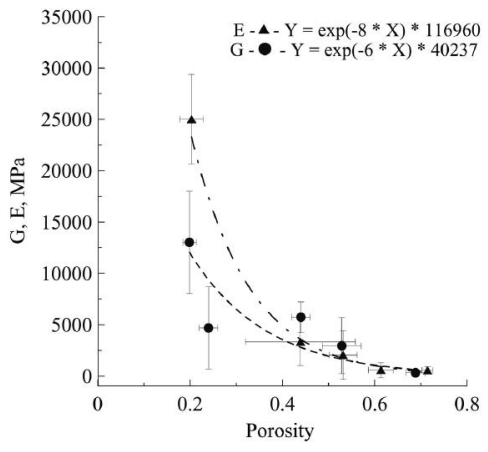

(c)

Fig. 4. Dependence of: (a) compressive strength, (b) shear strength, (c) modulus of elasticity and shear modulus values on pore space volume of alumina ceramics

4. ábra Aluminium-oxid kerámiák nyomó (a) és nyíró (b) szilárdsága, rugalmassági és nyírási modulusa (c) a pórustérfogat függvényében

that during deformation in compression and shear, there was a transition from a typically brittle state for relatively dense ceramics ( $\leq 20 \%$ porosity), to a pseudo-plastic state with a high porosity level (over 50\%).

The values of the modulus of elasticity, shear modulus and Poisson's ratio all decrease with an increase in pore space volume of $\mathrm{Al}_{2} \mathrm{O}_{3}$ ceramics, which correlates with the appearance of multiple cracking in the course of the deformation of highly porous ceramics.

It was shown that during deformation in compression, the failure process was controlled by shear stresses, which leads to the formation of damage in the shape of cones in the internal volume of the specimen, the size and location of which depend on the pore space volume.

\section{Acknowledgement}

Part of this work is financially supported by Tomsk State University Competitiveness Improvement Program and Siberian Branch Program \#III.23.2.3.

\section{References}

[1] Ren, F. - Case, E. D. - Morrison, A. - Tafesse, M. - Baumann, M. J. : Resonant ultrasound spectroscopy measurement of Young's modulus, shear modulus and Poisson's ratio as a function of porosity for alumina and hydroxyapatite; (2009) Philosophical Magazine, v. 89/14, pp. 1163-1182

[2] Gömze, László A. - Gömze, Ludmila N.: Advanced Hetero-Modulus and Hetero-Viscous Complex Materials; (2013) Materials Science Forum, v. 729, pp. $43-48$

[3] Kageyama, Kensuke - Harada, Youhei - Kato, Hiroshi: Preparation and Mechanical Properties of Alumina-Zirconia Composites with Agglomerated Structures Using Pre-Sintered Powder; (2003) Materials Transactions, v. 44, No. 8, pp. 1571-1576

[4] Kurosawa, Shunsuke - Bispo, Lucas - Shoji, Yasuhiro - Seki, Mafuyu - Yokota, Yuui - Chubaci, Jose F. D. - Yoshikawa, Akira: TL Properties of Pure $\mathrm{Al}_{2} \mathrm{O}_{3}$ Grown by the Micro-Pulling down Method; (2014) Key Enginering Materials v. 616, pp. 87-91; http://dx.doi.org/10.4028/www.scientific.net/KEM.616.87

[5] Fischer, H. - Marx, R.: Fracture toughness of dental ceramics: comparision of bending and indentation method; (2002) Dental Materials, v. 18, No. 1, pp. 12-19

[6] Fernando, J. A. - Chung, D. D. L. : Thermomechanical properties of alumina fiber membrane; (2005) Ceramics International, v. 31, pp. 453460, http://dx.doi.org/10.1016/j.ceramint.2004.06.010

[7] Corrêa de Sá, Maria Cecilia - de Moraes, Benevides - Elias, Carlos Nelson - Filho, Jamil Duailibi - Guimarães de Oliveira, Leandra: Mechanical properties of alumina-zirconia composites for ceramic abutments; (2004) Mat. Res. v.7 No.4 São Carlos Oct./Dec. 2004
[8] Kalatur, E. S. - Kozlova, A. V. - Buyakova, S. P. - Kulkov, S.N. : Deformation behavior of zirconia-based porous ceramics, (2013) IOP Conf. Ser.: Mater. Sci. Eng. 47012004 http://dx.doi.org/10.1088/1757-899X/47/1/012004

[9] Hakuta, Y. - Nagai, N. - Suzuki, Y. H. - Kodaira, T. - Bando, K. K. Takashima, H. - Mizukami, F.: Preparation of $\alpha$-alumina nanoparticles with various shapes via hydrothermal phase transformation under supercritical water conditions; (2013) IOP Conf. Ser.: Mater. Sci. Eng. 47 012045 http://dx.doi.org/10.1088/1757-899X/47/1/012045

[10] Savchenko, N. L. - Sablina, T. Yu. - Poletika, T. M. - Artish, A. S. - Kulkov, S. N.: High-temperature sintering in vacuum of plasma-chemical powders based on $\mathrm{ZrO}_{2}$; (1994) Powder metallurgy, No. 1-2, pp. 26-30.

[11] Stefanov, Yu.P.: Modes of dilatancy and deformation development condensation in localized shear zones; (2010) Physical mesomechanics, v.13, Spec. Edition, p.44-52.

[12] Goldshtein, R. V.: Damage under compression; (2003) Mechanics advances, v. 2, p. 3-17

[13] Phani, K. K.: Correlation between ultrasonic shear wave velocity and Poisson's ratio for isotropic porous materials; (2008) J. Mater. Sci., 43, pp 316-323

[14] Dunn, Martin L. - Ledbetter, Hassel: Poisson's ratio of porous and microcracked solids: Theory and application to oxide superconductors; (1995) Journal of Materials Research, v. 10/11, pp 2715-2722

[15] Kulkov, S. N. - Maslovskiy, V. I. - Buyakova, S. P. - Nikitin, D. S.: NonHookean behavior of porous zirconium dioxide under active compression deformation; (2002) Technical physics journal, v. 72/3, pp. 38-42

[16] Kulkov, S. N. - Buyakova, S. P. - Maslovskiy, V. I.: Micromechanical instability under porous ceramic materials deformation (2004). Physical mesomechanics, 7, Spec. Edition. v. 1, pp. 131-134.

\section{Ref.:}

Savchenko, N. L. - Sevostyanova, I. N. - Sablina, T. Y. - Molnár, L. Géber, R. - Gömze, L. A. - Kulkov, S. N. - Gömze, L. N.: The Influence of Porosity on the Elasticity and Strength of Alumina Ceramics Építöanyag - Journal of Silicate Based and Composite Materials, Vol. 66, No. 2 (2014), 44-47. p. http://dx.doi.org/10.14382/epitoanyag-jsbcm.2014.9

\section{A porozitás hatása alumínium-oxid kerámiák} szilárdságára és rugalmasságára

Jelen munkában a szerzốk a 18\%-70\% porozitású alumíniumoxid kerámiák szilárdsági és deformációs tulajdonságait vizsgálják nyomó és nyíró feszültségek hatására. A vizsgálatok során kapott „feszültség-deformáció” görbék azt mutatják, hogy a nagy súrúségú (porozitás $\leq 20 \%$ ) tipikusan rideg $\mathrm{Al}_{2} \mathrm{O}_{3}$ kerámia a pórustérfogat arányának növelésével (50\% felett) átalakul pszeudo-plasztikus anyaggá. Ugyanakkor az alumínium-oxid kerámiák rugalmassági modulusa, nyírási modulusa és Poisson tényezôje jelentôs mértékben csökken a pórustérfogat arányának növekedésével.

Kulcsszavak: alumínium-oxid, deformáció, rugalmassági modulus, képlékenység, porozitás, nyírás, szilárdság, feszültség, fajlagos alakváltozás 